\title{
Evaluation of atmospheric concentrations of dl-PCBs comparing to PCDD/F compounds in Istanbul, Turkey
}

\author{
Gunes G. ${ }^{1}$, and Saral A. ${ }^{2}$ \\ ${ }^{1}$ Bartin University, Engineering Faculty, Department of Environmental Engineering, Kutlubey-Yazicilar 74110, Bartin, Turkey \\ ${ }^{2}$ Yildiz Technical University, Department of Environmental Engineering, Esenler 34220, Istanbul, Turkey \\ Received: 19/10/2018, Accepted: 02/12/2018, Available online: 03/12/2018 \\ *towhom all correspondence should be addressed: e-mail: ggunes@bartin.edu.tr, saral@yildiz.edu.tr \\ https://doi.org/10.30955/gnj.002921
}

\begin{abstract}
In this study, the seasonal variation of atmospheric concentrations of PCDD/F and DI-PCB and the effect of meteorological factors on concentration were investigated. Ambient air samples were collected monthly between May 2011 and October 2013 by using high volume samplers. Based on these samples, average $\mathrm{PCDD} / \mathrm{F}$ and $\mathrm{dl}-\mathrm{PCB}$ concentrations were obtained as $1590 \mathrm{fg} / \mathrm{m}^{3}$ and $4855 \mathrm{fg} / \mathrm{m}^{3}$ respectively. $P C D D / F$ congeners did show seasonal variations. $58 \%$ share in total PCDD/Fs belongs to winter season while $4 \%$ to summer season. No significant seasonal change has been observed for dl-PCBs. 92\% $\left(1397 \mathrm{fg} / \mathrm{m}^{3}\right)$ of PCDD/Fs were detected in particulate phase while $20 \%\left(926 \mathrm{fg} / \mathrm{m}^{3}\right)$ of dl-PCBs were found in particulate phase. Strong negative correlations were obtained between all homolog groups and T, UV, SR. Correlation between five-chlorinated dl-PCBs, the most abandoned homolog group, with $T$, UV and SR generated positive meaningful correlation. No meaningful correlations were observed with other parameters. Correlations with particle phase were found to be more meaningful compared to gas phase for both $\mathrm{PCDD} / \mathrm{F}_{\mathrm{s}}$ and $\mathrm{dl}-\mathrm{PCB}_{\mathrm{s}}$.
\end{abstract}

Keywords: Polychlorinated dibenzo- $p$-dioxin/furan, dioxin-like PCB, ambient air, active air sampler, meteorological parameters.

\section{Introduction}

Polychlorinated dibenzo-p-dioxins/furans (PCDD/Fs) and polychlorinated biphenyls (PCBs) are the two most important groups of persistent organic pollutants (POPs) which are regulated in Stockholm Convention (Stockholm Convention, 2009). Chemical properties and toxicity values of 12 compounds among PCB group (PCB77, PCB81, PCB105, PCB114, PCB118, PCB123, PCB126, PCB156, PCB157, PCB167, PCB169, PCB189) are similar to PCDD/Fs so that they are called dioxin-like PCBs (dl-PCBs). At high doses, they show similar adverse health effects on humans similar to like PCDD/Fs (Pereira, 2004). Their vapour pressures are low and, they have low octanol-air (Koa) and high octanol-water (Kow) coefficients (Mackay et al., 2006). These properties affect many behavior and trends of PCBs such as gas/particle partitioning, transportation and abatement in the atmosphere, resistance against biological and chemical decompositions reactions, accumulations in the environmental and biological media. While PCDD/F compounds exist dominantly in particulate phase in the atmosphere, dl-PCBs exist in gaseous phase (Wethington and Hornbuckle, 2005; Gambaro et al., 2004). Low chlorinated PCBs tend to exist in gaseous phase because of their higher vapour pressures while higher chlorinated ones tend to exist in particle phase because of their lower vapour pressures (Kouimtzis et al., 2002; Mandalakis et al., 2002; Eitzer and Hites, 1989; Oh et al., 2001; Chao et al., 2004).

Gas phase PCBs are generally removed from the atmosphere by hydroxyl radicals or photochemical reactions (Atkinson, 1987; Kwok et al., 1994; Brubaker and Hites, 1997), while those in particle phase are removed by wet/dry deposition mechanisms (Lohmann and Jones, 1998).

Studies show that these chemicals have been emitted into the environment mainly from combustion sources and PCB containing commercial products (Brown et al., 1995; Simcik et al., 1997). PCB-like semi volatile organic compounds, after emitted from sources, they are transported by atmospheric transportation mechanisms and accumulate in the environmental media such as soil, water bodies and sediments. They may desorp from those sinks and re-enter into the atmosphere because of their semi-volatility.

The most important sources of PCDD/Fs are combustion processes (waste combustion, open burning, domestic heating, internal combustion engines), chemical production processes, metal smelting, iron-steel smelting (Tuppurainen et al., 1998; McKay, 2002; Buekens and Huang, 1998; Ni et al., 2009; Li et al., 2016; Liu et al., 2013a). While PCDD/Fs are formed as unwanted by-products from thermal processes, the case is different 
for PCBs. The emissions of PCBs are generally originate from i) the storage of $P C B$ containing wastes (electric transformers and capacitors, printer inks, resin products, hydraulic systems, vacuum pumps) and ii) thermal disposal of PCB containing wastes (Aries et al., 2004; Choi et al., 2008). Besides, recent studies show that thermal formation mechanisms of $\mathrm{PCBs}$ are somewhat similar to those of PCDD/Fs (Abad et al., 2006; Weber et al., 2001; Brubaker and Hites, 1998). Considering the fact that PCBs are precursors of the formations of PCDD/Fs, the sources causing the formation of PCDD/Fs will also be responsible for the formation of PCBs. For example, iron sintering (Liu et al., 2013b) and metal production processes cause the formation and emission of PCDD/Fs as well as dl-PCBs ( $\mathrm{Ba}$ et al., 2009a,b). Studies have shown that atmospheric concentrations of PCDD/Fs and dl-PCBs at industrial ( $\mathrm{Li}$ et al., 2012; Die et al., 2015) and urban (Deng et al., 2011; Li et al., 2014) areas are higher than those at rural areas (Thuan et al., 2013; Shih et al., 2006).

Atmospheric concentrations of PCDD/Fs and dl-PCBs are greatly affected by diversity and intensity of sources, mechanisms of wet/dry depositions and meteorological parameters (pressure, mixing height, temperature, precipitation, UV-solar radiation, humidity).

In this study, atmospheric concentrations and behaviors of PCDD/ F and dl-PCB compounds were investigated. Their seasonal and spatial variations, gas/particle distributions were compared and their similarities and differences were determined.In addition, the relationship between meteorological parameters and congeners was investigated by statistical analysis.

\section{Experimental/methodology}

\subsection{Study area}

Ambient air samples were collected at three sampling stations in Istanbul as shown in Figure 1 . Site 1 may be characterized by industrial+urban pollutant sources where there are many small scale industrial settlements (industrial zones) and considerable city traffic load especially from the intercity bus station which is the biggest of Turkey. Site 2 may be characterized by only urban pollutant sources where the traffic (motor vehicles) is the dominant pollution source. Site 3 may be considered as rural area which is far from city center and having no industrial activity in the immediate vicinity. However, medical and incineration plant are present at $8 \mathrm{~km} \mathrm{NE}$ of the sampling station (Figure 1, Site 4).

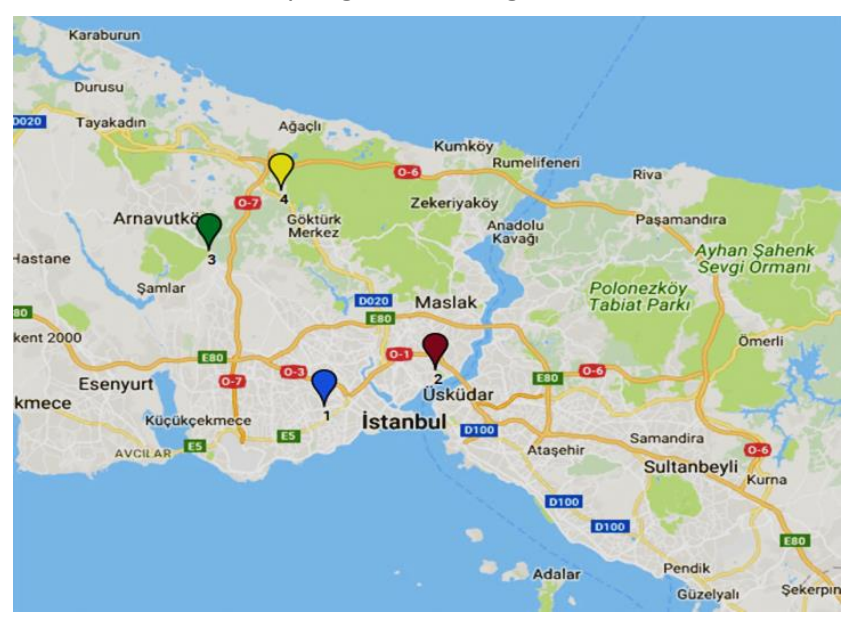

Figure 1. Characteristics of sampling locations

Table 1. Meteorological parameters related to sampling campaign

\begin{tabular}{|c|c|c|c|c|c|c|c|c|c|}
\hline & $T\left(C^{0}\right)$ & $\begin{array}{c}\text { UV } \\
\text { (index) }\end{array}$ & $\begin{array}{c}\text { SR } \\
\left(W / m^{2}\right) \\
\end{array}$ & $\begin{array}{c}\text { WV } \\
(\mathrm{m} / \mathrm{s})\end{array}$ & RH (\%) & $P(m b)$ & $R(\mathbf{m m})$ & $\begin{array}{c}\text { Mixing } \\
\text { Height }(\mathrm{m})\end{array}$ & $\operatorname{TSP}\left(\mu \mathrm{g} / \mathrm{m}^{3}\right)$ \\
\hline \multirow[t]{2}{*}{ Spring } & 15,4 & 1,6 & 213 & 3 & 67 & 1015 & 12 & 374 & 88 \\
\hline & $(10,7-23)$ & $(0,9-2,1)$ & (111-257) & $(2,0-3,6)$ & $(58-80)$ & $(1010-1025)$ & $(0,1-41)$ & & $(68-135)$ \\
\hline \multirow[t]{2}{*}{ Summer } & 24 & 2,1 & 252 & 3,7 & 77 & 1010 & 4,7 & 530 & 50 \\
\hline & $(21-26)$ & $(1,8-2,6)$ & $(229-304)$ & $(2,7-5,4)$ & $(71-84)$ & $(1005-1012)$ & $(0,1-20,1)$ & & $(36-60)$ \\
\hline \multirow[t]{2}{*}{ Autumn } & 15 & 0,9 & 116 & 3 & 79 & 1017 & 10 & 639 & 65 \\
\hline & $(7-21)$ & $(0,4-1,1)$ & $(53-175)$ & $(2,3-4,3)$ & $(70-86)$ & $(1012-1018)$ & $(1,8-32)$ & & $(43-117)$ \\
\hline \multirow[t]{2}{*}{ Winter } & 6,8 & 0,5 & 68 & 4 & 79 & 1016 & 14 & 541 & 60 \\
\hline & $(3-10)$ & $(0,2-0,8)$ & $(37-114)$ & $(3,1-5,1)$ & $(74-83)$ & $(1011-1020)$ & $(11-18)$ & & $(33-114)$ \\
\hline
\end{tabular}

T: Temperature, UV: Ultra Violet, SR: Solar Radiation, WV: Wind Velocity, RH: Humidity, P: Pressure, R: Rain, TSP: Total Suspended Particle

\subsection{Sampling and analysis}

Ambient air samples were collected monthly between May 2011 and October 2013 by using high volume samplers (TCR Techora-Echo). High volume air samplers were operated at $0.225 \mathrm{~m}^{3} \mathrm{~min}^{-1}$ flow rate for the period of

5-7 days at each sampling station. Total volumes of air samples were between 746-2242 $\mathrm{m}^{3}$. Quartz fiber (QF) and polyurethane foam (PUF) filters were used for the sampling of gas and particle phases. Meteorological parameters were also measured and recorded by wireless weather stations (Davis Vantage Pro 2) at each sampling station (Table 1). Sampling and analyses were conducted in accordance with the reference method EPA TO-9A (US EPA, 1999). Detailed information about analytical process was reported in the literature (Gunes et al., 2014; Gunes and Saral, 2014; Saral et al., 2015).

\section{Results and discussion}

Average $\mathrm{PCDD} / \mathrm{F}$ concentration was obtained as $1590 \mathrm{fg} / \mathrm{m}^{3}$ (ranging between 893 and $2700 \mathrm{fg} / \mathrm{m}^{3}$ ) having median value of $1178 \mathrm{fg} / \mathrm{m}^{3}$ and standard deviation (SD) of \pm 972 . Corresponding average international toxicity 
equivalent quantity (I-TEQ) value was calculated as $112 \mathrm{fg} / \mathrm{m}^{3}$ I-TEQ with the median of $85 \mathrm{fg} / \mathrm{m}^{3}$ and SD of \pm 54 . Average dl-PCB concentration was obtained as $4855 \mathrm{fg} / \mathrm{m}^{3}$ (ranging between 3529 and $5773 \mathrm{fg} / \mathrm{m}^{3}$ ) with the median of 5263 , SD of \pm 1176 . The average of I-TEQ values of dl-PCBs were calculated as $11 \mathrm{fg} / \mathrm{m}^{3}$ with a range between 7 to $15 \mathrm{fg} / \mathrm{m}^{3}$. Contribution of dl-PCBs to total TEQ was calculated as $9 \%$ (Figure 2 ).

At this time there is no ambient air concentration standard for PCDD/F in Turkey. The average value obtained in this study ( $112 \mathrm{fg} / \mathrm{m}^{3}$ I-TEQ) was compared to the standard given for Japan (Japan's Environmental

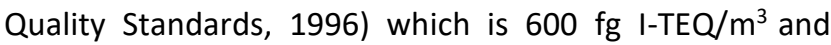
found to be fairly lower than an ambient standard. Average I-TEQ value was found within the range $\left(100-400 \mathrm{fg}\right.$ I-TEQ $\left./ \mathrm{m}^{3}\right)$ reported for urban areas by Lohmann and Jones (2000).

Studies in the literature reported dl-PCB concentrations of $6 \mathrm{fg} \mathrm{I-TEQ} / \mathrm{m}^{3}$ for industrial regions and $2 \mathrm{fg} \mathrm{l}-\mathrm{TEQ} / \mathrm{m}^{3}$ for residential areas in Anshan city, China (Li et al., 2010). Another study in China reported winter and summer $\mathrm{PCDD} / \mathrm{F}$ concentrations of 83.4 and $63.4 \mathrm{fg} \mathrm{TEQ} / \mathrm{m}^{3}$, respectively (Tian et al., 2015). Li et al. (2011) reported $\mathrm{PCDD} / \mathrm{F}$ concentration of $74 \mathrm{fg} \mathrm{TEQ} / \mathrm{m}^{3}$ for industrial regions. Martinez et al. (2010) evaluated the transportation by wind. They determined dl-PCB concentration of $23 \mathrm{fg} \mathrm{I}-\mathrm{TEQ} / \mathrm{m}^{3}$ when the wind blows from industrial region and $12 \mathrm{fg} \mathrm{I}-\mathrm{TEQ} / \mathrm{m}^{3}$ when the wind blows from residential region. Another study recorded $26.2 \mathrm{pg} / \mathrm{m}^{3}$ of dl-PCB concentration in the vicinity of an iron-steel plant and $3.3 \mathrm{pg} / \mathrm{m}^{3}$ in urban area (Choi et al., 2008).

\subsection{Spatial distribution of $P C D D / F$ and $d l-P C B$ concentrations}

Order of magnitudes of the concentrations may be given as site 1 (urban-industrial) > site 2 (urban) > site 3 (rural) which was expected when the distribution of sources is considered as explained in Section 2.1 (Figure 2). Motor vehicle traffic is thought to be the most important source of PCDD/Fs and dl-PCBs as site 1 and site 2 measurements indicated. Mass concentrations for PCDD/Fs measured at site 1 are compatible with the study conducted in Taiwan where measurements (3.5-5.7 $\mathrm{pg} \mathrm{m}^{-3}$ ) were taken in the vicinity of a waste incineration plant (Chao et al., 2004) and the study conducted in Shanghai in winter season $\left(2.3 \mathrm{pg} \mathrm{m}^{-3}\right)$ at an industrial area (Die et al., 2015). Respective records of dl-PCBs at site 1 and site 2 are 5.77 and $5.26 \mathrm{pg} \mathrm{m}^{-3}$ which are compatible with the value of $5.4 \mathrm{pg} \mathrm{m}^{-3}$ in Toronto (Helm and Bidleman, 2003) and with the value of $5.4 \mathrm{pg} \mathrm{m}^{-3}$ in Netherland (Lopez Garcia et al., 1996) both of which studies were conducted in urban sites away from city centers.

Site 3 is far away from the city center being at the edge of forest area and surrounded by villages. There is a highway near this station but the traffic load is light. $3.54 \mathrm{pg} / \mathrm{m}^{3}$ average concentration of dl-PCBs at this station is compatible with the study $\left(3.3 \mathrm{pg} \mathrm{m}^{-3}\right)$ conducted by
Choi et al. (2008) for residential areas, but somewhat higher than the result of the study $\left(1.2 \mathrm{pg} / \mathrm{m}^{3}\right)$ conducted in the USA at rural and remote areas (Cleverly et al., 2007). Average I-TEQ concentrations of dl-PCBs at sites 1 and 2 were found to be 15 and $10 \mathrm{fg}$ I-TEQ/m $\mathrm{m}^{3}$ respectively, which are somewhat greater than the study conducted at industrial area (steel plant) (6 fg l-TEQ/ $/ \mathrm{m}^{3}$ ) by Li et al. (2010).

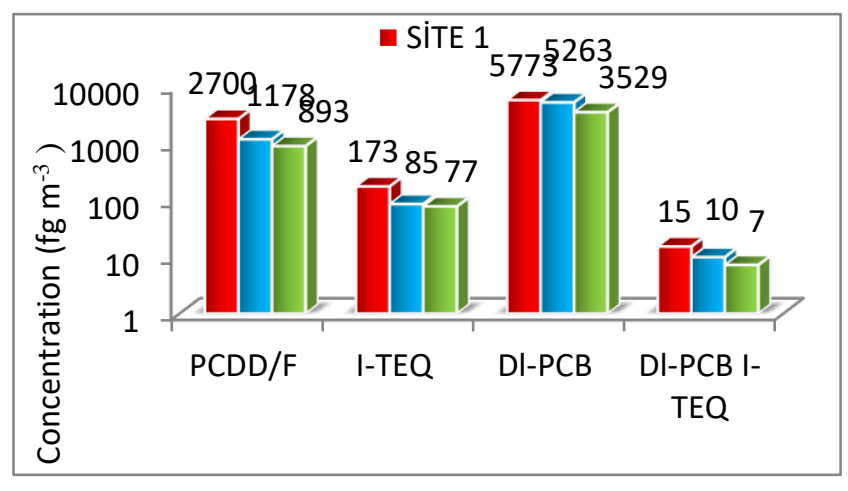

Figure 2. Spatial variation of PCDD/Fs and dl-PCBs

\subsection{Congener profiles of $P C D D / F$ and dI-PCB compounds}

Statistical evaluations for PCDD/Fs and dl-PCBs were given in Table 2. The ratio of PCDD congeners is $38 \%$ and the rest (62\%) is that of PCDFs in total PCDD/Fs concentration. This distribution is compatible with the literature stating that the congeners profile of atmospheric PCDD/Fs are dominantly characterized by PCDF congeners (Oh et al., 2002; Lee et al., 2007). The congeners contributing in highest ratios to total $\mathrm{PCDD} / \mathrm{F}$ concentration are OCDD (22\%) and 1,2,3,4,6,7,8-HpCDF (15\%), 1,2,3,4,6,7,8-HpCDD (\%11), OCDF (\%10). Those dominant among PCDDs are OCDD (55\%) and 1,2,3,4,6,7,8-HpCDD (29\%). Primary sources of these congeners are motor vehicles with unleaded gasoline and diesel trucks (Cleverly et al., 1997). The congener OCDD mainly originates from combustion most important sources of which are solid waste incineration, unleaded gasoline and diesel truck emissions, wood and heavy oil combustion processes (Cleverly et al., 1997). Contribution of 2,3,7,8-TCDD is $0,7 \%$ being the most toxic one. Among PCDF congeners, 1,2,3,4,6,7,8-HpCDF contributes 25\%, 1,2,3,4,7,8,9-HpCDF and OCDF contribute $16 \%$ to the total as the highest ones while $1,2,3,7,8,9-\mathrm{HxCDF}$ shares $1 \%$ being the least contributing congener. Unlike 2,3,7,8-TCDD, 2,3,7,8-TCDF contributes with $5,6 \%$ share in total PCDF concentration. OCDD, HpCDF, HpCDD were determined as dominant congeners in studies conducted by Abad et al. (2007), Ariztizabal et al. (2011), OCDD, HpCDD, OCDF were reported as dominant congeners for rainy and dry season in another study conducted in Taiwan (Trinh et al., 2018). OCDD, 1,2,3,4,6,7,8-HpCDF, 1,2,3,4,6,7,8-HpCDD, OCDF were determined as dominant congeners at all sampling points. Only $2,3,4,7,8,9-\mathrm{HpCDF}$ demonstrated $28 \%$ contribution in winter season at Site 1 . This fact leads us to think that different fuels other than coal might be used for heating purpose in winter at the residential areas 
around site 1. Having this congener with about 2\% contribution in other seasons at all sampling sites validates this thought.

Dominant PCB congeners among dl-PCBs were detected to be two of 5-chlorinated ones as PCB118 with 51\% contribution and PCB105 with $20 \%$, and one of 4-chlorinated ones as PCB77 with $10 \%$ contribution. Similar congener profiles were reported in the literature (Choi et al., 2008; Cleverly et al., 2007; Trinh et al., 2018). The congener with the least contribution was a 6-chlorinated PCB169 with 1,2\%. The highest percentage in total I-TEQ concentration is $87 \%$ which belongs to PCB126 (5-Cl), followed by PCB169 (6-Cl) with 5\%, PCB77 (4-Cl) with $2 \%$ and PCB118 (5-Cl) with $2 \%$. PCB118, PCB105 and PCB77 again shared the highest contributions when considering sampling sites and seasons individually. Martinez et al. (2010) reported PCB118, PCB105 and PCB77 as the dominant congeners at urban and industrial (steelwork) areas. Similar congener profile was also obtained in a survey conducted to search the effect of Asian dusts on ambient air PCB concentrations (Chi et al., 2008). Other studies did report almost the same congener profiles of dl-PCBs in the ambient air (Helm and Bidleman, 2005; Cleverly et al., 2007; Choi et al., 2008; Castro-Jiménez et al., 2008). Again, PCB118, PCB105 and PCB77 shared respective contributions of 50\%, 20\% and $15 \%$ in Eastern Asian contries (Trinh and Chang, 2018).

\subsection{Comparison of gas/particle partitioning of $P C D D / F$ and dl-PCB compounds}

$92 \%\left(1397 \mathrm{fg} / \mathrm{m}^{3}\right)$ of PCDD/Fs were detected in particulate phase and the rest $8 \%\left(129 \mathrm{fg} / \mathrm{m}^{3}\right)$ in gas phase, while $80 \%$ $\left(3780 \mathrm{fg} / \mathrm{m}^{3}\right)$ of $\mathrm{dl}-\mathrm{PCBs}$ were found in gas phase and the rest $20 \%\left(926 \mathrm{fg} / \mathrm{m}^{3}\right)$ in particulate phase. Similar results were reported in the literature (Lohmann and Jones, 1998; Yeo et al., 2003). Particulate phase percentage of $\mathrm{PCDD} / \mathrm{Fs}$ is found to be greater in urban site (94\%) compared to rural area (84\%). Similar comparison was also reported by $\mathrm{Chi}$ et al. (2008) where $65 \%$ and $77 \%$ percentages were recorded for PCDD/Fs at rural and urban areas, respectively. Similar trend was also detected for dl-PCBs in particulate phase as $36 \%$ at urban and $20 \%$ at rural areas. For both PCDD/Fs and dl-PCBs, particulate phase share increases as the number of chlorine increases. For example, particulate phase shares of TCDD (4-Cl), 1,2,3,4,6,7,8-HPCDD (7-Cl) and OCDD (8-Cl) were recorded to be $0,004,0,12$ and 0,23 , respectively. Particulate phase fraction of PCB77 was 0,1 while that of PCB118 was 0,5. On the other hand, since vapour pressures of PCDDs are lower that PCDFs, particulate phase fraction (96\%) of PCDDs is greater than that (89\%) of PCDFs. This result is compatible with the result reported by Li et al. (2008).

Annual mean Total Suspended Particle (TSP) concentration was determined as $67 \mu \mathrm{\mu g} / \mathrm{m}^{3}$. Total Suspended Particulate concentrations at site 1,2 and 3 were measured to be 164, 125 and $78 \mu \mathrm{g} / \mathrm{m}^{3}$, respectively. Seasonal variation of TSP was observed as spring: $87 \mu \mathrm{g} / \mathrm{m}^{3}$, summer: $59 \mu \mathrm{g} / \mathrm{m}^{3}$, autumn: $65 \mu \mathrm{g} / \mathrm{m}^{3}$ and winter: $66 \mu \mathrm{g} / \mathrm{m}^{3}$. Similar result was reported by Kuzu
(2016) on 3 February. Though TSP in spring was recorded to be relatively high, a weak correlation $\left(r: 0,4 ; r^{2}: 0,2\right)$ was obtained between TSP and particulate phase PCDD/F concentration. This case may be explained by pollens released from trees causing higher TSP in the ambient air in spring. In summer, on the other hand, relatively stronger correlations were obtained between TSP and PCDD/Fs (r: 0,88; $\left.r^{2}: 0,78\right)$, and dl-PCBs ( $\left.r: 0,67 ; r^{2}: 0,45\right)$. Especially at site 3 , much higher summer correlations for both PCDD/Fs ( $\left.r, 0.92 ; r^{2}: 0,85\right)$ and dl-PCBs ( $r: 0,87$; $\left.r^{2}: 0,76\right)$ were obtained.

In winter, in which combustion for residential heating is dominant, correlations between TSP and PCDD/Fs was as $\left(r: 0,8 ; r^{2}: 0,64\right)$ and dl-PCBs was as $\left(r: 0,72 ; r^{2}: 0,52\right)$ which are relatively high. Emissions from combustion sources for heating which cause increase in the concentrations of both TSP and particle phase congeners support this result. Moreover Li et al. (2010, 2016) state that biomass combustion cause increase in both TSP and particulate phase PCDD/F concentrations.

\subsection{Seasonal variation of gas/particle partitioning of $P C D D / F$ and $d I-P C B$}

PCDD/F compounds did show seasonal variations. Considerable difference occurred between summer and winter. $58 \%$ share in total PCDD/Fs belongs to winter season being $4088 \mathrm{fg} / \mathrm{m}^{3}$ while $4 \%$ to summer as $276 \mathrm{fg} / \mathrm{m}^{3}$. The great difference between summer and winter figures may be explained by the dominant emissions from heating purpose combustion sources in winter. Similar results were reported by researchers in the literature (Li et al., 2011; Huang et al., 2011, Qin et al., 2012; Chi et al., 2013). Unlike PCDD/Fs, dl-PCBs did not show significant seasonal variations. Concentrations in summer and winter were recorded as 4699 and $5225 \mathrm{fg} / \mathrm{m}^{3}$, respectively. Shares of summer and winter seasons in total concentration were calculated as $24 \%$ and $26 \%$, respectively. Similarly, Fiedler et al. (1999) reported that the seasonal trend of dl-PCBs was the opposite of dioxins. $P / G$ (particle/gas) ratio of PCDD/Fs for summer and winter were calculated as 2 and 25, respectively. Particulate and gas phase concentrations in summer were 190 and $107 \mathrm{fg} / \mathrm{m}^{3}$ while those in winter were 3930 and $158 \mathrm{fg} / \mathrm{m}^{3}$. Summer and winter shares of total gas phase concentration for PCDD/Fs were $20 \%$ and $30 \%$, while those for particulate phase were $3 \%$ and $62 \%$, respectively. Share of gas phase is higher in winter than in summer (Figure 3). This case could be explained by a source which becomes dominant in winter thought to be combustion for heating. This source also caused increase in particulate phase share in winter. Considering the sampling sites, the highest gas phase share for summer was detected at site $3(22 \%)$ while the lowest was at site $2(12 \%)$. As partially stated before, various ratios of $P / G$ distribution of PCDD/Fs may be reasoned by the factors of temperature, physico-chemical properties of compounds (molecular weight, chlorine content, vapour pressure), sources and formation mechanisms. 
Table 2. Statistical coefficients related to PCDD/F and PCB compounds

\begin{tabular}{|c|c|c|c|c|c|c|c|c|c|c|c|c|c|c|c|c|}
\hline \multirow{2}{*}{ Congeners $\left(\mathrm{fg} \mathrm{m}^{-3}\right)$} & \multicolumn{6}{|c|}{ SITE 1} & \multicolumn{5}{|c|}{ SITE 2} & \multicolumn{5}{|c|}{ SITE 3} \\
\hline & $\mathbf{N}$ & Mean & Median & SD & Min & Max & Mean & Median & SD & Min & Max & Mean & Median & SD & Min & Max \\
\hline 2,3,7,8-TCDD & 28 & 14 & 12 & 12 & 1,6 & 34 & 8 & 6 & 7 & 2 & 24 & 4 & 3 & 3 & 2 & 12 \\
\hline $1,2,3,7,8-P c D D$ & 28 & 36 & 26 & 32 & 2 & 115 & 17 & 12 & 19 & 3 & 75 & 10 & 7 & 10 & 2 & 40 \\
\hline $1,2,3,4,7,8-\mathrm{HxCDD}$ & 28 & 25 & 22 & 18 & 4,54 & 69 & 14 & 11 & 12 & 3 & 52 & 11 & 9 & 7 & 3 & 24 \\
\hline $1,2,3,6,7,8-\mathrm{HxCDD}$ & 28 & 38 & 28 & 36 & 2,4 & 138 & 22 & 16 & 22 & 4 & 91 & 15 & 11 & 13 & 2 & 46 \\
\hline $1,2,3,7,8,9-\mathrm{HxCDD}$ & 28 & 32 & 16 & 31 & 2,4 & 115 & 19 & 12 & 22 & 4 & 91 & 15 & 10 & 15 & 2 & 57 \\
\hline 1,2,3,4,6,7,8,-HpCDD & 28 & 278 & 136 & 286 & 12,3 & 1033 & 158 & 87 & 186 & 6 & 839 & 98 & 47 & 106 & 8 & 363 \\
\hline OCDD & 28 & 488 & 213 & 524 & 38 & 1721 & 348 & 151 & 443 & 12 & 1957 & 161 & 87 & 179 & 8 & 655 \\
\hline PCDD & & 910 & 455 & 938 & 63 & 3225 & 587 & 295 & 710 & 34 & 3128 & 315 & 174 & 332 & 27 & 1197 \\
\hline $2,3,7,8-\mathrm{TCDF}$ & 28 & 89 & 57 & 93 & 5 & 339 & 40 & 27 & 49 & 3 & 217 & 37 & 17 & 54 & 4 & 264 \\
\hline $1,2,3,7,8-\mathrm{PeCDF}$ & 28 & 92 & 47 & 106 & 4 & 427 & 42 & 25 & 54 & 2 & 231 & 34 & 21 & 40 & 3 & 162 \\
\hline $2,3,4,7,8-\mathrm{PeCDF}$ & 28 & 121 & 63 & 143 & 3 & 567 & 54 & 34 & 68 & 3 & 313 & 40 & 21 & 46 & 4 & 192 \\
\hline $1,2,3,4,7,8-\mathrm{HxCDF}$ & 28 & 131 & 72 & 146 & 7 & 631 & 56 & 34 & 65 & 6 & 287 & 52 & 34 & 47 & 4 & 186 \\
\hline $1,2,3,6,7,8-\mathrm{HxCDF}$ & 28 & 146 & 76 & 168 & 8 & 688 & 63 & 34 & 79 & 4 & 356 & 51 & 30 & 50 & 4 & 182 \\
\hline $1,2,3,7,8,9-\mathrm{HxCDF}$ & 28 & 15 & 11 & 11 & 5 & 44 & 8 & 6 & 5 & 1 & 17 & 7 & 6 & 3 & 4 & 14 \\
\hline $2,3,4,6,7,8-\mathrm{HxCDF}$ & 28 & 124 & 70 & 136 & 6 & 574 & 56 & 41 & 58 & 5 & 252 & 55 & 36 & 52 & 7 & 194 \\
\hline $1,2,3,4,6,7,8-\mathrm{HpCDF}$ & 28 & 404 & 187 & 503 & 35 & 2410 & 148 & 88 & 192 & 4 & 908 & 161 & 107 & 149 & 19 & 589 \\
\hline $1,2,3,4,7,8,9-\mathrm{HpCDF}$ & 28 & 422 & 44 & 1848 & 4 & 9471 & 25 & 16 & 29 & 1 & 133 & 27 & 26 & 17 & 5 & 77 \\
\hline OCDF & 28 & 245 & 161 & 290 & 15 & 1377 & 100 & 69 & 133 & 8 & 576 & 115 & 69 & 131 & 12 & 625 \\
\hline PCDF & & 1789 & & & & & 591 & & & & & 578 & & & & \\
\hline $\mathrm{PCDD} / \mathrm{F}$ & & 2699 & & & & & 1178 & & & & & 893 & & & & \\
\hline \multirow{2}{*}{ Congeners (fg m ${ }^{-3}$ ) } & \multirow{2}{*}{\multicolumn{4}{|c|}{\begin{tabular}{|ll}
\multicolumn{2}{|c|}{ SITE 1} \\
Median & SD
\end{tabular}}} & & & \multicolumn{5}{|c|}{ SITE 2} & \multicolumn{5}{|c|}{ SITE 3} \\
\hline & & & & & Min & Max & Mean & Median & SD & Min & Max & Mean & Median & SD & Min & Max \\
\hline РCB 77 & 28 & 76 & 624 & 487 & 242 & 2542 & 494 & 448 & 239 & 237 & 1187 & 340 & 279 & 256 & 0,13 & 1171 \\
\hline РCB 81 & 28 & 95 & 89 & 55 & 15 & 201 & 46 & 48 & 19 & 12 & 80 & 56 & 47 & 61 & 2,6 & 233 \\
\hline PCB 126 & 28 & 131 & 106 & 118 & 17 & 412 & 88 & 68 & 90 & 4,7 & 350 & 55 & 39 & 43 & 6 & 148 \\
\hline PCB 169 & 28 & 77 & 71 & 40 & 14 & 136 & 61 & 45 & 46 & 28 & 152 & 38 & 31 & 34 & 3,1 & 85 \\
\hline PCB 105 & 28 & 1225 & 1140 & 459 & 383 & 2063 & 1040 & 1022 & 290 & 649 & 1635 & 727 & 767 & 263 & 76 & 1471 \\
\hline PCB 114 & 28 & 121 & 107 & 69 & 46 & 305 & 87 & 61 & 56 & 40 & 278 & 66 & 64 & 31 & 6,6 & 145 \\
\hline PCB 118 & 28 & 3314 & 2923 & 1216 & 1641 & 5693 & 2770 & 2581 & 939 & 1335 & 4564 & 1705 & 1627 & 712 & 174 & 3478 \\
\hline PCB 123 & 28 & 82 & 79 & 39 & 28 & 166 & 67 & 62 & 37 & 22 & 160 & 51 & 48 & 31 & 4,7 & 121 \\
\hline PCB 156 & 28 & 318 & 325 & 138 & 119 & 669 & 325 & 286 & 183 & 123 & 1072 & 217 & 191 & 118 & 25 & 479 \\
\hline PCB 157 & 28 & 87 & 80 & 45 & 26 & 171 & 72 & 63 & 35 & 32 & 182 & 57 & 40 & 36 & 8 & 118 \\
\hline PCB 167 & 28 & 152 & 157 & 59 & 63 & 302 & 144 & 130 & 71 & 53 & 337 & 98 & 97 & 53 & 7,56 & 179 \\
\hline РСB 189 & 28 & 95 & 101 & 51 & 17 & 202 & 69 & 47 & 53 & 13 & 163 & 119 & 51 & 231 & 2,71 & 901 \\
\hline Total DI-PCB & & 5773 & & & & & 5263 & & & & & 3529 & & & & \\
\hline
\end{tabular}

N: Sample Number, SD: Standard Deviation 
G/P ratios of dl-PCBs were calculated as 6.4 for summer and 2.2 for winter. Gas phase concentrations in summer and winter were $4127 \mathrm{fg} / \mathrm{m}^{3}$ and $3724 \mathrm{fg} / \mathrm{m}^{3}$ while those for particulate phase were $647 \mathrm{fg} / \mathrm{m}^{3}$ and $1732 \mathrm{fg} / \mathrm{m}^{3}$ respectively (Figure 3 ). Seasonal variation of average gas phase concentrations was not significant with the figures of $26 \%$ and $24 \%$ for summer and winters shares. Unlike this study, other researchers (Chi et al., 2008; Kim et al., 2011; Min et al., 2013).) have reported that more than $90 \%$ of $\mathrm{dl}-\mathrm{PCBs}$ are in the gas phase in summer. Cetin et al. (2017) reported that the concentration of PCB (mostly non-dioxin-like PCB) increased with temperature in the study conducted in 4 different sampling periods in Istanbul. On the other hand, particulate phase shares in seasons showed somewhat remarkable change as $38 \%$ in winter and $14 \%$ in summer. Possible mechanisms and reasons stated in Section 3.4 are thought to be valid here. Moreover, summer time desorption of dl-PCBs was also stated by Halsall et al. (1995) and Tasdemir et al. (1997).

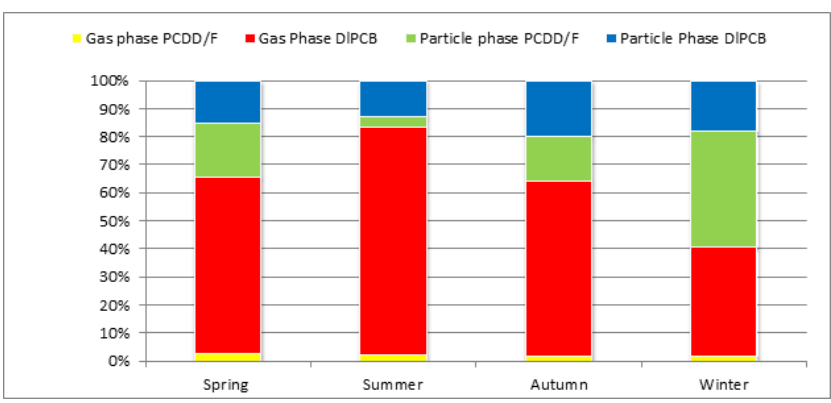

Figure 3. Seasonal variation of gas/particle concentrations of $\mathrm{PCDD} / \mathrm{F}_{\mathrm{s}}$ and $\mathrm{DI}-\mathrm{PCB}_{\mathrm{s}}$

\subsection{Relationships between meteorological parameters and congeners}

In this Section, relationships between atmospheric concentrations of $\mathrm{PCDD} / \mathrm{F}$ and $\mathrm{dl}-\mathrm{PCB}$ compounds to meteorological parameters were evaluated. Table 3 summarizes the seasonal averages (with max and $\mathrm{min}$ ) of those parameters. Strong negative correlations were obtained between all homolog groups and T, UV, SR as given in Table 3.

Negative correlation between PCDD/Fs and $\mathrm{T}$ may be explained by increasing fossil fuel consumption with decreasing $T$ in winter. High $r^{2}$ values support this idea. Another strong negative correlation between PCDD/Fs and UV-SR may be explained by decomposition of PCDD/Fs via photochemical reactions under high UV and solar radiation together with the lack of fossil fuel combustion in summer. No significant correlation was observed with $\mathrm{WV}, \mathrm{RH}$ and rain while moderately positive correlation were obtained between concentration and pressure. High pressure causes descending air masses, decreased transportation and eventually accumulation of pollutants in the atmosphere.

There exist significant negative correlations between gas phase concentrations of $4-5$ chlorinated PCDD/Fs and T,
UV and SR, while no meaningful correlations were detected with higher chlorinated ones. Effect of combustion of fossil fuels in winter may be the cause of negative correlation between low chlorinated ones and temperature. Negative correlation with UV and SR may be explained by recessive effect of these parameters with dominant effect of emission sources in winter, while the opposite way in summer. As stated before, photochemical reactions caused by UV and SR might also cause decomposition of these congeners.

Lee et al. (2008) also reported negative correlations between PCDD/Fs and UV - SR. In another lab scale study, a strong negative correlation was also reported between PCDD/Fs and ozone together with UV (Atkinson, 1997). No meaningful correlations were obtained between PCDD/Fs with wind velocity and rain both of which might be the main removal mechanisms from the atmosphere for those pollutants. Correlations with particle phase were found to be more meaningful compared to gas phase. Strong negative correlations were observed between all homologs with T, UV and SR while positive correlation with pressure. Multiple regression with $T$, UV and SR generated strong negative correlation $\left(r:-0.78, r^{2}: 0.62\right.$, p: 0,00) with all homologs.

Correlation between five-chlorinated dl-PCBs, the most abandoned homolog group, with T UV and SR generated positive meaningful correlation. No meaningful correlations were observed with other parameters. For gas phase concentrations, a positive correlation was detected between five-chlorinated group with T, UV and $\mathrm{SR}$. The reason for this situation was explained in detail in the following section.

Negative correlation was detected between pressure and gas phase concentration with relatively smaller regression coefficient indicating that a variety of factors affect this relation. High pressures were generally recorded in winter months with low temperatures and this causes transport towards and increase in particulate phase concentration. A very weak negative correlation was observed between gas phase and rain which may indicate wet deposition and eventually decrease in gas phase concentration.

Negative correlations were observed between particulate phase concentrations of all homolog groups of dl-PCBs with T, UV and SR. Increasing chlorine content showed increase in correlations. Though wind velocity and humidity were reported to be effective on the atmospheric concentrations of dl-PCBs (Burgoyne and Hites, 1993; Hornbuckle and Eisenreich, 1996), no meaningful relations were observed (including rain, and PCDD/Fs also) between in this study. An exception may be stated as in the case of January 2012 in which sampling period a snow just after the rainfall considerably affected the atmospheric concentrations of these compounds. The average TSP concentration was determined as 69 $\mu \mathrm{g} / \mathrm{m}^{3}$ in December 2011 and $33 \mu \mathrm{g} / \mathrm{m}^{3}$ in January 2012. Similarly, Chan and Kwok (2001) and Trinh et al. (2018) 
determined the TSP concentration lower in the rainy season than in the dry season. The PCDD/F particle phase concentration was determined to be $6658 \mathrm{fg} / \mathrm{m}^{3}$ and $1680 \mathrm{fg} / \mathrm{m}^{3}$ for December 2011 and January 2012, respectively. This can be explained by the removal of the particulate phase PCDD/F compounds from the atmosphere by rainfall and snowfall. Since PCDD/Fs existed in particulate phase by $90 \%$, they have been removed in relatively much more fraction by wet deposition. Morover, it was determined that the effect of rain and snow on dl-pcb concentration is negligible. The gas phase concentration of DI-PCBs decreased by $26 \%$ in January 2018. Similarly, Trinh et al. (2018) reported that TSP and PCDD/F concentrations were lower in the rainy season than dry season unlike dl-PCB compounds. Negative correlations were observed between PCDD/Fs and mixing height with the correlation and regression coefficients of $\left(r:-0.66 ; r^{2}: 0.53\right)$ in winter and ( $r:-0.68$; $r^{2}: 0.51$ ) in summer. It is well known that as mixing height increases concentration decreases.

3.6. The effect of meteorological parameters on atmospheric gas phase concentrations of $P C D D / F_{s}$ and $D I-P C B_{s}$

The variation of the atmospheric gas phase concentrations of the semi volatile organic compounds depending on the temperature was investigated by using Clausius-Clapeyron equation (Eq.(1)) by many researchers (Sofuoglu et al., 2004; Bozlaker et al., 2008; Kuzu et al., 2014). These researchers also investigated the effects of wind speed and wind direction on the gas phase concentration of these compounds by using Eq. (1) and multiple regression analysis.

$\ln P=m(1 / T)+b$

Where, $P$ partial pressures of congeners (atm), $\mathrm{m}$ slope, $\mathrm{T}$ average atmospheric temperature (K), $b$ intercept. The effect of ultraviolet radiation (UV), wind speed and rainfall as well as temperature on gas phase concentration of $\mathrm{PCDD} / \mathrm{F}_{\mathrm{s}}$ and $\mathrm{dl}-\mathrm{PCB}_{\mathrm{s}}$ was investigated by using Eq. (2) with the multiple linear regression analysis in this study and the results are shown in Table 4.

$\mathrm{InP}=m_{1}(1 / \mathrm{T})+m_{2} \mathrm{UV}+m_{3} \mathrm{WR}+m_{4} \mathrm{R}+b$

Where, $\mathrm{P}$ partial pressures of congeners (atm), $\mathrm{T}$ average atmospheric temperature (K), UV ultraviolet radiation (index), WR wind rate $(\mathrm{m} / \mathrm{s}), \mathrm{R}$ rainfall $(\mathrm{mm}), \mathrm{m}_{1}, \mathrm{~m}_{2} \mathrm{~m}_{3}$, $\mathrm{m}_{4}$ and $b$ regression parameters. Since negative slope values were determined for all homologous groups of dl-PCBs it is thought that the gas phase concentrations increase with increasing temperature.
Generally, shallow slope values and low regression coefficients were determined for all homologous groups. Shallow slope and low $r^{2}$ values are explained by continuous sources, advection, wet/dry deposition, atmospheric reactions and long-distance transport of atmospheric air mass (Sofuoğlu et al., 2004). According to Eq. (2), shallow and statistically insignificant $\mathrm{m} 1$ values were determined for dl-PCBs. Shallow, negative slope values were determined for 4,5 and $7 \mathrm{Cl}$-PCBs. For this reason, it is considered that the atmospheric gas phase concentrations of dl-PCBs may be affected by long-range transport. Another reason may be a decrease in particulate matter concentration as temperature increases during the summer. Thus, PCBs may tend to be in the gas phase during the summer. A medical waste incineration plant located at a certain distance from the sampling points (20 km from sampling points 1 and 2 and $8 \mathrm{~km}$ from sampling point 3) can be the reason for long range transport. This situation is supported by the dominance of low-chlorinated PCBs in incineration plants (Jansson et al., 2011). In another study conducted in Istanbul, it was reported that non dl-PCB concentration increased with temperature and high negative slope values were explained by desorption from terrestrial areas (Kuzu et al., 2014). Similarly, Cetin et al. (2017) reported that the PCB concentration increased with temperature. Statistically significant results were obtained for the 4,5 and 7 chlorinated homologues of PCDD/F compounds. As the positive shallow $\mathrm{m}_{1}$ values for the $4,5 \mathrm{Cl}-\mathrm{PCDD} / \mathrm{F}$ homologs are determined, it can be said that these homologs are affected by the continuous sources. Negative and shallow slope values for $6-7 \mathrm{Cl}-\mathrm{PCDD} / \mathrm{F}$ can be explained by long-range transport, advection, wet/dry deposition and atmospheric reactions. According to the results of multiple regression, a shallow positive $\mathrm{m} 1$ for mostly negative shallow negative PCDD/Fs was determined for dl-PCBs

According to multiple regression results, a shallow negative $\mathrm{m} 1$ values were determined for $\mathrm{dl} / \mathrm{PCB}_{\mathrm{s}}$ while a shallow positive $\mathrm{m} 1$ values were determined for PCDD/F compounds. However, the results are not statistically significant. Positive $m_{2}$ values were determined for all PCDD/F and dl-PCB homologs except 4 and 5 chlorinated $\mathrm{PCDD} / \mathrm{F}$ homologs and the results are statistically insignificant. For this reason it is thought that UV is not related to the gas phase concentration of these compounds. Negative $m_{3}$ values were determined for all PCDD/F homologs (except 8 chlorinated homologs) and 4 chlorinated PCB homologs. For this reason, at higher wind speeds these compounds are swept from the atmosphere by advection. However, the results are not statistically significant. Statistical results show that rainfall is not effective on the gas phase concentrations of PCDD/Fs and PCBs. Similarly, Trinh et al. (2018) reported that the scavenging effect of higher rainfall on the dl-PCB gas phase concentration is weak. 
Table 3. Statistical coefficients related to meteorological parameters and PCDD/Fs and DI-PCBs homologues

\begin{tabular}{|c|c|c|c|c|c|c|c|c|c|c|c|c|c|c|c|c|c|c|c|c|c|c|c|}
\hline & & & \multicolumn{3}{|c|}{$\mathrm{T}\left({ }^{\circ} \mathrm{C}\right)$} & \multicolumn{3}{|c|}{ UV (index) } & \multicolumn{3}{|c|}{$\mathrm{SR}\left(\mathrm{W} / \mathrm{m}^{2}\right)$} & \multicolumn{3}{|c|}{ WV $(\mathrm{m} / \mathrm{s})$} & \multicolumn{3}{|c|}{$H(\%)$} & \multicolumn{3}{|c|}{$P(\mathrm{mb})$} & \multicolumn{3}{|c|}{$R(\mathrm{~mm})$} \\
\hline & & & $\mathbf{R}$ & $\mathrm{R}^{2}$ & $p$ & $\mathbf{R}$ & $\mathbf{R}^{2}$ & $p$ & $\mathbf{R}$ & $\mathbf{R}^{2}$ & $p$ & $\mathbf{R}$ & $\mathbf{R}^{2}$ & $p$ & $\mathbf{R}$ & $\mathbf{R}^{2}$ & $p$ & $\mathbf{R}$ & $\mathbf{R}^{2}$ & $p$ & $\mathbf{R}$ & $\mathbf{R}^{2}$ & $p$ \\
\hline \multirow{15}{*}{$\mathrm{PCDD} / \mathrm{F}$} & \multirow{5}{*}{ GAS PHASE } & $4 \mathrm{Cl}$ & $-0,6$ & 0,37 & 0,002 & $-0,6$ & 0,32 & 0,005 & $-0,5$ & 0,25 & 0,014 & 0,007 & 0,00 & 0,97 & $-0,1$ & 0,01 & 0,65 & 0,2 & 0,04 & 0,37 & 0,2 & 0,04 & 0,35 \\
\hline & & $5 \mathrm{Cl}$ & $-0,75$ & 0,6 & 0,00 & $-0,6$ & 0,4 & 0,001 & $-0,6$ & 0,3 & 0,003 & 0,00 & 0,00 & 0,94 & 0,1 & 0,00 & 0,61 & 0,6 & 0,3 & 0,01 & 0,1 & 0,00 & 0,51 \\
\hline & & $6 \mathrm{Cl}$ & 0,29 & 0,09 & 0,17 & 0,39 & 0,15 & 0,06 & 0,48 & 0,23 & 0,02 & $-0,41$ & 0,16 & 0,055 & $-0,6$ & 0,36 & 0,003 & $-0,15$ & 0,02 & 0,51 & $-0,05$ & 0,00 & 0,81 \\
\hline & & $7 \mathrm{Cl}$ & 0,37 & 0,14 & 0,105 & 0,47 & 0,23 & 0,03 & 0,56 & 0,31 & 0,011 & $-0,27$ & 0,07 & 0,25 & $-0,36$ & 0,13 & 0,12 & $-0,15$ & 0,02 & 0,53 & $-0,29$ & 0,09 & 0,21 \\
\hline & & $8 \mathrm{Cl}$ & 0,07 & 0,00 & 0,82 & 0,39 & 0,15 & 0,15 & 0,29 & 0,08 & 0,3 & $-0,15$ & 0,02 & 0,6 & 0,33 & 0,11 & 0,23 & $-0,21$ & 0,04 & 0,45 & $-0,1$ & 0,01 & 0,76 \\
\hline & \multirow{5}{*}{$\begin{array}{l}\text { PARTICLE } \\
\text { PHASE }\end{array}$} & $4 \mathrm{Cl}$ & $-0,67$ & 0,45 & 0,00 & $-0,61$ & 0,37 & 0,002 & $-0,59$ & 0,35 & 0,003 & 0,11 & 0,01 & 0,6 & 0,17 & 0,03 & 0,45 & 0,33 & 0,11 & 0,12 & 0,05 & 0,0 & 0,83 \\
\hline & & $5 \mathrm{Cl}$ & $-0,75$ & 0,56 & 0,00 & $-0,63$ & 0,39 & 0,001 & $-0,59$ & 0,34 & 0,003 & 0,02 & 0,0 & 0,93 & 0,519 & 0,01 & 0,61 & 0,55 & 0,31 & 0,006 & 0,14 & 0,02 & 0,51 \\
\hline & & $6 \mathrm{Cl}$ & $-0,78$ & 0,61 & 0,00 & $-0,65$ & 0,43 & 0,001 & $-0,58$ & 0,34 & 0,004 & $-0,04$ & 0,0 & 0,86 & 0,01 & 0,00 & 0,95 & 0,6 & 0,36 & 0,003 & 0,12 & 0,02 & 0,57 \\
\hline & & $7 \mathrm{Cl}$ & $-0,44$ & 0,2 & 0,03 & $-0,5$ & 0,25 & 0,015 & $-0,48$ & 0,23 & 0,02 & 0,29 & 0,1 & 0,17 & 0,19 & 0,04 & 0,4 & 0,16 & 0,03 & 0,46 & 0,17 & 0,03 & 0,43 \\
\hline & & $8 \mathrm{Cl}$ & $-0,66$ & 0,43 & 0,001 & $-0,53$ & 0,29 & 0,009 & $-0,43$ & 0,19 & 0,04 & $-0,11$ & 0,01 & 0,63 & $-0,1$ & 0,00 & 0,78 & 0,6 & 0,37 & 0,002 & 0,05 & 0,0 & 0,8 \\
\hline & \multirow{5}{*}{ GAS+PARTICLE } & $4 \mathrm{Cl}$ & $-0,76$ & 0,58 & 0,00 & $-0,68$ & 0,46 & 0,00 & $-0,63$ & 0,4 & 0,001 & 0,02 & 0,00 & 0,94 & 0,1 & 0,01 & 0,68 & 0,41 & 0,17 & 0,05 & 0,17 & 0,03 & 0,45 \\
\hline & & $5 \mathrm{Cl}$ & $-0,76$ & 0,58 & 0,00 & $-0,65$ & 0,42 & 0,001 & $-0,6$ & 0,36 & 0,002 & 0,01 & 0,00 & 0,96 & 0,06 & 0,00 & 0,8 & 0,55 & 0,3 & 0,006 & 0,18 & 0,03 & 0,41 \\
\hline & & $6 \mathrm{Cl}$ & $\begin{array}{l}-0,76 \\
\end{array}$ & 0,58 & 0,00 & $\begin{array}{l}-0,64 \\
\end{array}$ & 0,41 & 0,001 & $-0,56$ & 0,31 & 0,006 & $-0,1$ & 0,00 & 0,77 & $-0,02$ & 0,00 & 0,91 & 0,6 & 0,36 & 0,003 & 0,11 & 0,01 & 0,62 \\
\hline & & $7 \mathrm{Cl}$ & $-0,44$ & 0,19 & 0,036 & $-0,5$ & 0,25 & 0,015 & $-0,48$ & 0,23 & 0,021 & 0,29 & 0,09 & 0,17 & 0,19 & 0,04 & 0,38 & 0,16 & 0,02 & 0,47 & 0,17 & 0,03 & 0,44 \\
\hline & & $8 \mathrm{Cl}$ & $-0,65$ & 0,42 & 0,001 & $-0,51$ & 0,26 & 0,013 & $-0,4$ & 0,16 & 0,16 & $-0,13$ & 0,02 & 0,55 & $-0,1$ & 0,01 & 0,001 & 0,64 & 0,42 & 0,001 & 0,02 & 0,00 & 0,92 \\
\hline \multirow{12}{*}{ DL-PCB } & \multirow{4}{*}{ GAS PHASE } & $4 \mathrm{Cl}$ & 0,26 & 0,1 & 0,24 & 0,5 & 0,1 & 0,25 & 0,34 & 0,12 & 0,11 & $-0,16$ & 0,1 & 0,46 & $-0,44$ & 0,2 & 0,04 & $-0,12$ & 0,1 & 0,6 & $-0,1$ & 0,1 & 0,7 \\
\hline & & $5 \mathrm{Cl}$ & 0,5 & 0,24 & 0,02 & 0,6 & 0,34 & 0,003 & 0,6 & 0,32 & 0,005 & 0,2 & 0,04 & 0,36 & $-0,2$ & 0,03 & 0,4 & $-0,44$ & 0,2 & 0,034 & $-0,14$ & 0,02 & 0,51 \\
\hline & & $6 \mathrm{Cl}$ & $-0,1$ & 0,1 & 0,7 & 0,11 & 0,1 & 0,62 & 0,1 & 0,1 & 0,75 & 0,2 & 0,1 & 0,41 & $-0,1$ & 0,1 & 0,68 & 0,1 & 0,00 & 0,88 & $-0,12$ & 0,1 & 0,58 \\
\hline & & $7 \mathrm{Cl}$ & 0,28 & 0,1 & 0,32 & 0,23 & 0,1 & 0,44 & 0,3 & 0,1 & 0,35 & 0,13 & 0,1 & 0,65 & $-0,1$ & 0,00 & 0,83 & $-0,2$ & 0,1 & 0,5 & $-0,2$ & 0,1 & 0,52 \\
\hline & \multirow{4}{*}{$\begin{array}{l}\text { PARTICLE } \\
\text { PHASE }\end{array}$} & $4 \mathrm{Cl}$ & $-0,25$ & 0,1 & 0,26 & $-0,3$ & 0,1 & 0,2 & $-0,24$ & 0,1 & 0,3 & $-0,02$ & 0,00 & 0,92 & $-0,12$ & 0,01 & 0,57 & 0,14 & 0,02 & 0,56 & 0,23 & 0,1 & 0,28 \\
\hline & & $5 \mathrm{Cl}$ & $-0,5$ & 0,2 & 0,02 & $-0,35$ & 0,12 & 0,1 & $-0,33$ & 0,11 & 0,12 & 0,1 & 0,1 & 0,66 & $-0,1$ & 0,1 & 0,65 & 0,2 & 0,03 & 0,65 & 0,1 & 0,1 & 0,64 \\
\hline & & $6 \mathrm{Cl}$ & $-0,64$ & 0,41 & 0,001 & $-0,67$ & 0,44 & 0,001 & $-0,66$ & 0,44 & 0,001 & 0,14 & 0,1 & 0,55 & 0,13 & 0,02 & 0,58 & 0,55 & 0,3 & 0,008 & 0,22 & 0,1 & 0,32 \\
\hline & & $7 \mathrm{Cl}$ & $\begin{array}{l}-0,71 \\
\end{array}$ & 0,5 & 0,002 & $\begin{array}{l}-0,64 \\
\end{array}$ & 0,41 & 0,007 & $-0,6$ & 0,33 & 0,02 & 0,34 & 0,1 & 0,2 & 0,2 & 0,1 & 0,42 & 0,51 & 0,26 & 0,05 & 0,1 & 0,1 & 0,77 \\
\hline & \multirow{4}{*}{$\begin{array}{l}\text { GAS+ PARTICLE } \\
\text { PHASE }\end{array}$} & $4 \mathrm{Cl}$ & 0,2 & 0,0 & 0,43 & 0,1 & 0,0 & 0,56 & 0,2 & 0,0 & 0,32 & $-0,1$ & 0,0 & 0,51 & $-0,3$ & 0,1 & 0,14 & $-0,1$ & 0,0 & 0,7 & $-0,1$ & 0,0 & 0,7 \\
\hline & & $5 \mathrm{Cl}$ & 0,43 & 0,2 & 0,04 & 0,5 & 0,3 & 0,015 & 0,51 & 0,3 & 0,014 & 0,2 & 0,1 & 0,4 & $-0,2$ & 0,1 & 0,5 & $\begin{array}{l}-0,4 \\
\end{array}$ & 0,2 & 0,06 & $-0,2$ & 0,1 & 0,32 \\
\hline & & $6 \mathrm{Cl}$ & $-0,3$ & 0,1 & 0,13 & $-0,2$ & 0,1 & 0,46 & $-0,2$ & 0,1 & 0,45 & 0,2 & 0,1 & 0,45 & 0,0 & 0,0 & 0,99 & 0,3 & 0,1 & 0,19 & $-0,2$ & 0,1 & 0,47 \\
\hline & & & $-0,1$ & 0,0 & 0,95 & $-0,1$ & 0,1 & 0,8 & 0,1 & 0,0 & 0,88 & 0,2 & 0,1 & 0,47 & $-0,1$ & 0,0 & 0,83 & 0,1 & 0,1 & 0,7 & $-0,2$ & 0,1 & 0,47 \\
\hline \multicolumn{24}{|c|}{$\begin{array}{l}\text { T:Temperature, UV: Ultra Violet, SR: Solar Radiation, WV: Wind Velocity, H: Humidity, P: Pressure, R: Rain } \\
\text { Table 4. Regression parameters for Eq. (1) and Eq. (2) }\end{array}$} \\
\hline & & $m_{1}$ & & $m_{2}$ & & & $\mathrm{~m}_{4}$ & & $\mathbf{p}_{1}$ & $p_{2}$ & & 3 & $\mathrm{p}_{4}$ & & $r^{2}$ & $\mathrm{~m}$ & & P1 & & $\mathbf{r}^{2}$ & & $n$ & \\
\hline $4 \mathrm{Cl}$ & $\mathrm{CDD} / \mathrm{F}$ & 3799 & & $-0,15$ & & & 0,01 & & 0,16 & 0,63 & & 29 & 0,51 & & 0,42 & 49 & & 0,00 & & 0,36 & & 23 & \\
\hline $5 \mathrm{Cl}$ & $\mathrm{CDD} / \mathrm{F}$ & 2766 & & $-0,11$ & & & 0,01 & & 0,27 & 0,71 & & 21 & 0,42 & & 0,34 & 36 & & 0,01 & & 0,25 & & 23 & \\
\hline $6 \mathrm{Cl}$ & $\mathrm{CDD} / \mathrm{F}$ & 66 & & 0,15 & & & 0,00 & & 0,96 & 0,40 & & 09 & 0,93 & & 0,26 & -10 & & 0,21 & & 0,07 & & 23 & \\
\hline $7 \mathrm{Cl}$ & $\mathrm{CDD} / \mathrm{F}$ & 2576 & & 0,76 & & & $-0,01$ & & 0,30 & 0,02 & & 22 & 0,16 & & 0,53 & -32 & & 0,02 & & 0,25 & & 20 & \\
\hline $8 \mathrm{Cl}$ & $\mathrm{CDD} / \mathrm{F}$ & 3787 & & 0,69 & & & $-0,01$ & & 0,11 & 0,07 & & 82 & 0,50 & & 0,33 & 2 & & 0,99 & & 0,00 & & 15 & \\
\hline & PCB & $\begin{array}{l}-507 \\
\end{array}$ & & 0,1 & & & 0,00 & & 0,83 & 0,64 & & 69 & 0,97 & & 0,1 & -14 & & 0,25 & & 0,1 & & 23 & \\
\hline & $\mathrm{PCB}$ & -656 & & 0,4 & & & 0,00 & & 0,74 & 0,11 & & 35 & 0,95 & & 0,4 & -30 & & 0,01 & & 0,3 & & 23 & \\
\hline & $\mathrm{PCB}$ & 1670 & & 0,27 & & & $-0,01$ & & 0,33 & 0,20 & & 34 & 0,47 & & 0,1 & -2 & & 0,83 & & 0,0 & & 23 & \\
\hline & PCB & $-96,6$ & & 0,456 & & & $-0,014$ & & 0,99 & 0,57 & & 34 & 0,61 & & 0,2 & -21 & & 0,40 & & 0,3 & & 14 & \\
\hline
\end{tabular}




\section{Conclusions}

Average atmospheric concentrations of $\mathrm{PCDD} / \mathrm{F}_{\mathrm{s}}$ was found to be about $30 \%$ of that of $\mathrm{dl}-\mathrm{PCB}_{\mathrm{s}}$. Increasing chlorine content increased the PCDD/Fs concentration in contrast to dl-PCBs. Seasonal variation is more apparent for PCDD/Fs. Concentration ratio of winter to summer was about 15 , while that for dl-PCBs was 1,1 . Therefore, it was thought that fossil fuel combustion sources for heating affected PCDD/Fs concentrations much more than dl-PCBs. Moreover, statistical coefficients of relation $\left(r: 0,5, r^{2}: 0,24, p: 0,002\right)$ determined between temperature and gas phase concentration of dl-PCBs implied that their desorption from sinks was not considerable. PCDD/Fs were found in gas phase in $8 \%$ while dl-PCBs were in $80 \%$. Temperature, number of chlorine atoms and vapour pressure were observed to be the most important parameters affecting gas/particle partitioning of congeners. As number of chlorine increases and temperature decreases, fraction of particulate phase increased. In addition shallow, negative slope values were determined for 4,5 and $7 \mathrm{Cl}-\mathrm{PCBs}$. For this reason, it is considered that the atmospheric gas phase concentrations of dl-PCBs were not affected by volatilization from soil and water surfaces.

Statistical relations determined between particulate phase concentrations and meteorological parameters were observed to be more meaningful compared to those for gas phase concentrations. Since particle phase fractions of PCDD/Fs were found to be much higher than those of dl-PCBs, statistical relations between meteorological parameters and PCDD/Fs were found to be more meaningful.

\section{References}

Abad E., Martinez K., Caixach J. and Rivera J. (2006), Polychlorinated dibenzo-p-dioxins, dibenzofurans and 'dioxin-like' PCBs in flue gas emissions from municipal waste management plants, Chemosphere, 63, 570-580.

Abad E., Martínez K., Gustems L., Gómez R., Guinart X., Hernández I. and Rivera J. (2007), Ten years measuring PCDDs/PCDFs in ambient air of Catalonia (Spain), Chemosphere, 67, 1709-1714.

Aries E., Anderson D.R., Ordsmith N., Hall K. and Fisher R. (2004), Development and validation of a method for analysis of "dioxin-like" PCBs in environmental samples from the steel industry, Chemosphere, 54, 23-31.

Aristizábal B.H., Gonzalez C.M., Morales L., Abalos M., Abad, E., 2011. Polychlorinated dibenzo-p-dioxin and dibenzofuran in urban air of an Andean city. Chemosphere 85, 170-178.

Atkinson R. (1987), Estimation of $\mathrm{OH}$ radical reaction rate constants and atmospheric lifetimes for polychlorobiphenyls, dibenzo-p-dioxins, and dibenzofurans, Environmental Science \& Technology, 21(3), 305-307.

Atkinson R. (1997), Atmospheric chemistry of PCBs, PCDDs and PCDFs. In: Issues in environmental science and technology 1997 No. 6: Chlorinated Organic Micropollutants, The Royal Society of Chemistry, 53-72.

Ba T., Zheng M.H., Zhang B., Liu W.B., Su G.J. and Xiao K. (2009a), Estimation and characterization of PCDD/Fs and dioxin-like
PCB emission from secondary zinc and lead metallurgies in China, Journal of Environmental Monitoring, 11(4), 867-872.

Ba T., Zheng M.H., Zhang B., Liu W.B., Xiao K. and Zhang L.F. (2009b), Estimation and characterization of PCDD/Fs and dioxin-like PCBs from secondary copper and aluminum metallurgies in China, Chemosphere, 75(9), 1173-1178.

Bozlaker A., Odabasi M. and Muezzinoglu A. (2008). Dry deposition and soil-air gas exchange of polychlorinated biphenyls (PCBs) in an industrial area, Environmental Pollution, 156, 784-93.

Brown Jr. J.F., Frame G.M., Olson D.R. and Webb J.L. (1995), The sources of coplanar PCBs, Organohalogen Compounds, 26, 427-430.

Brubaker W.W. and Hites R.A. (1997), Polychlorinated dibenzo-pdioxins and dibenzofurans: Gas-phase hydroxyl radical reactions and related atmospheric removal, Environmental Science \& Technology, 31(6), 1805-1810.

Brubaker W.W. and Hites R.A. (1998), Gas-phase oxidation products of biphenyl and polychlorinated biphenyls, Environmental Science \& Technology, 32(24), 3913-3918.

Buekens A. and Huang H. (1998), Comparative evaluation of techniques for controlling the formation and emission of chlorinated dioxins/furans in municipal waste incineration, Journal of Hazardous Materials, 62(1), 1-33.

Burgoyne T.W. and Hites R.A. (1993). Effects of temperature and wind direction on the atmospheric concentrations of a-Endosulfan, Environmental Science and Technology, 27, 910-914.

Castro-Jiménez J., Mariani G., Eisenreich S.J., Christoph E.H., Hanke G., Canuti E. and Skejo H. (2008), Atmospheric input of POPs into Lake Maggiore (Northern Italy): PCDD/F and dioxin-like $P C B$ profiles and fluxes in the atmosphere and aquatic system, Chemosphere, 73, 122-130.

Chan L.Y. and Kwok W.S. (2001), Roadside suspended particulates at heavily trafficked urban sites of Hong Kongseasonal variation and dependence on meteorological conditions, Atmospheric environment, 35(18), 3177-3182.

Chao M.R., Hu C.W., Chen Y.L., Chang-Chien G.P., Lee W.J., Chang L.W., Lee W.S. and Wu K.Y. (2004), Approaching gas-particle partitioning equilibrium of atmospheric PCDD/Fs with increasing distance from an incinerator: measurements and observations on modeling, Atmospheric environment, 38(10), 1501-1510.

Cetin B., Ozturk F., Keles M. and Yurdakul S. (2017), PAHs and PCBs in an Eastern Mediterranean megacity, Istanbul: Their spatial and temporal distributions, air-soil exchange and toxicological effects, Environmental Pollution, 220, 13221332.

Chi K.H., Hsu S.C., Wang S.H. and Chang M.B. (2008), Increases in ambient PCDD/F and PCB concentrations in Northern Taiwan during an Asian dust storm episode, Science of the Total Environment, 401, 100-108.

Chi K.H., Lin C.Y., Wang S.H., Lin N.H., Sheu G.R. and Lee C.T. (2013), Evaluation of the distributions of ambient PCDD/Fs at remote locations in and around Taiwan, Atmospheric environment, 78, 203-210.

Choi S.D., Baek S.Y. and Chang Y.S. (2008), Atmospheric levels and distribution of dioxin-like polychlorinated biphenyls (PCBs) and polybrominated diphenyl ethers (PBDEs) in the vicinity of an iron and steel making plant, Atmospheric Environment, 42, 2479-2488. 
Cleverly D., Ferrario J., Byrne C., Riggs K., Joseph D. and Hartford $P$. (2007), A general indication of the contemporary background levels of PCDDs, PCDFs, and coplanar PCBs in the ambient air over rural and remote areas of the United States, Environmental Science and Technology, 41, 1537-1544.

Cleverly D., Schaum J., Schweer G., Becker J. and Winters D. (1997), The congener profiles of anthropogenic sources of chlorinated dibenzo-p-dioxins and chlorinated dibenzofurans in the United States, Organohalogen Compounds, 32.

Deng Y., Peng P., Ren M., Song J. and Huang W. (2011), The winter effect on formation of PCDD/Fs in Guangzhou by vehicles: a tunnel study, Atmospheric Environment, 45(15), 2541-2548.

Die Q.Q., Nie Z.Q., Liu F., Tian Y.J., Fang Y.Y., Gao H.F., Tian S.L., He J. and Huang, Q.F. (2015), Seasonal variations in atmospheric concentrations and gas-particle partitioning of $\mathrm{PCDD} / \mathrm{Fs}$ and dioxin-like PCBs around industrial sites in Shanghai, China, Atmospheric Environment, 119, 220-227.

Eitzer B.D. and Hites R.A. (1989), Polychlorinated dibenzo-pdioxins and dibenzofurans in the ambient atmosphere of Bloomington, Indiana. Environmental Science and Technology, 23, 1389-1395.

Fiedler H. (1999), Compilation of EU Dioxin Exposure and Health Data, Task 2 - Environmental Levels - October 1999. Report produced for the European Commission DG Environment. UK Department of the Environment, Transport and the Regions (DETR).

Gambaro A., Manodori L., Moret I., Capodaglio G. and Cescon P. (2004), Determination of polychlorobiphenyls and polycyclic aromatic hydrocarbons in the atmospheric aerosol of the Venice Lagoon, Analytical and Bioanalytical Chemistry, 378(7), 1806-1814.

Government of Japan. Environmental Quality Standards in Japan - Air Quality, 2014. http://www.env.go.jp/)

Gunes G. and Saral A. (2014), Seasonal variation of PCDD/Fs in the metropolis of Istanbul, Turkey, Environmental Science and Pollution Research, 21, 8718-8729 DOI 10.1007/s11356014-2798-7.

Gunes G., Saral A., Celikten H., Kuzu S.L., Demir S. and Uygur N. (2014), Investigation of temporal and spatial variations in atmospheric concentrations of PCDDs and PCDFs in Istanbul. Science of The Total Environment, 488-489, 469-474. doi.org/10.1016/j.scitotenv.2013.10.094

Halsall C.J., Lee R.G.M., Coleman P.J., Burnett V., Harding-Jones P. and Jones K.C. (1995), PCBs in UK urban air, Environmental Science \& Technology, 29, 2368-2376.

Helm P.A. and Bidleman T.F. (2003), Current combustion-related sources contribute to polychlorinated naphthalene and dioxin-like polychlorinated biphenyl levels and profiles in air in Toronto, Canada, Environmental Science and Technology, 37, 1075-1082.

Helm P.A. and Bidleman T.F. (2005), Gas-particle partitioning of polychlorinated naphthalene and non- and mono orthosubstituted polychlorinated biphenyls in arctic air, Science of the Total Environment, 342, 161-173.

Hornbuckle K.C. and Eisenreich S.J. (1996), Dynamics of gaseous semivolatile organic compounds in terrestrial ecosystem effects of diurnal and seasonal climate variations, Atmospheric Environment, 30, 3935-3945.
Huang C.J., Chen K.S., Lai Y.C., Wang L.C. and Chang-Chien G.P. (2011), Wet deposition of polychlorinated dibenzo-pdioxins/dibenzofuran in a rural area of Taiwan, Aeros. Air Qual. Res., 11(6), 732-748.

Jansson S., Lundin L. and Grabic R. (2011), Characterisation and fingerprinting of $\mathrm{PCBs}$ in flue gas and ash from waste incineration and in technical mixtures, Chemosphere, 85, 509-515.

Kim D.G., Choi K.I. and Lee D.H. (2011), Gas-particle partitioning and behavior of dioxin-like PCBs in the urban atmosphere of Gyeonggi-do, South Korea, Atmospheric Research, 101(1-2), 386-395.

Kouimtzis T.H., Samara C., Voutsa D., Balafoutis C.H. and Müller L. (2002), PCDD/Fs and PCBs in air borne particulate matter of the greater Thessaloniki area, N. Greece, Chemosphere, 47, 193-205.

Kuzu S.L., Saral A., Summak G., Çoltu H. and Demir S. (2014), Ambient polychlorinated biphenyl levels and their evaluation in a metropolitan city, Science of the Total Environment, 472, 13-19.

Kuzu S.L., 2016. Compositional Variation of PCBs, PAHs, and OCPs at Gas Phase and Size Segregated Particle Phase during Dust Incursion from the Saharan Desertin the Northwestern Anatolian Peninsula, Advances in Meteorology, 1-12.

Kwok E.S.C., Arey J. and Atkinson R. (1994), Gas-phase atmospheric chemistry of dibenzo-pdioxin and dibenzofuran, Environmental Science \& Technology, 28(3), 528-533.

Lee S.J., Ale D., Chang Y.S., Oh J.E. and Shin S.K. (2008), Seasonal and particle size dependent variations in gas/particle partitioning of PCDD/Fs, Environmental Pollution, 153, 215-222.

Lee S.J., Park H., Choi S.D., Lee J.M. and Chang Y.S. (2007), Assessment of variations in atmospheric PCDD/Fs by Asian dust in southeastern Korea, Atmospheric Environment, 41 (28), 5876-5886.

Li H.R., Feng J.L., Sheng G.Y., Lü S.L., Fu J.M., Peng P.A. and Man R. (2008), The PCDD/F and PBDD/F pollution in the ambient atmosphere of Shanghai. China, Chemosphere, 70(4), 576583.

Li Y.M., Wang P., Ding L., Li X.M., Wang T., Zhang Q.H., Yang H.B., Jiang G.B. and Wei F.S. (2010), Atmospheric distribution of polychlorinated dibenzo-p-dioxins, dibenzofurans and dioxinlike polychlorinated biphenyls around a steel plant Area, Northeast China, Chemosphere, 79 (3), 253-258.

Li X.M., Li Y.M., Zhang Q.H., Wang P., Yang H.B., Jiang G.B. and Wei F.S. (2011), Evaluation of atmospheric sources of PCDD/Fs, PCBs and PBDEs around a steel industrial complex in northeast China using passive air samplers, Chemosphere, 84(7), 957-963.

Li C., Zheng M., Zhang B., Gao L., Liu L., Zhou X., Ma X. and Xiao K. (2012), Long-term persistence of polychlorinated dibenzop-dioxins and dibenzofurans in air, soil and sediment around an abandoned pentachlorophenol factory in China, Environmental Pollution, 162, 138-143.

Li H., Zhou L., Ren M., Sheng G., Fu J. and Peng, P.A. (2014), Levels, profiles and gas-- particle distribution of atmospheric $\mathrm{PCDD} / \mathrm{Fs}$ in vehicle parking lots of a South China metropolitan area, Chemosphere, 94, 128-134.

Li Y.C., Yang Y., Yu G., Huang J., Wang B., Deng S.B. and Wang Y.J. (2016), Emission of unintentionally produced persistent 
organic pollutants (UPOPs) from municipal waste incinerators in China, Chemosphere, 158, 17-23.

Liu G.R., Zheng M.H., Cai Z.W., Wu Y.N. and Jiang G.B. (2013a), Dioxin analysis in China, Trac-Trends in Analytical Chemistry, 46, 178-188.

Liu G.R., Zheng M.H., Cai M.W., Nie Z.Q., Zhang B., Liu W.B., Du B., Dong S.J., Hu J.C. and Xiao K. (2013b), Atmospheric emission of polychlorinated biphenyls from multiple industrial thermal processes, Chemosphere, 90(9), 2453-2460.

Lohmann R. and Jones K.C. (1998), Dioxins and furans in air and deposition: a review of levels, behaviour and processes, The Science of the Total Environment, 219(1), 53-81.

Lohmann R. and Jones K.C. (2000), Dioxins and furans in air and deposition: a review of levels, behavior and processes. The Science of the Total Environment, 219, 53-81.

Lopez Garcia A., Den Boer A.C. and De Jong A.P.J.M. (1996), Determination of non- and mono-ortho-polychlorinated biphenyls in background ambient air, Environmental Science and Technology, 30, 1032-1037.

Mackay D., Shiu W.Y., Ma K.C. and Lee S.C. (2006), Second ed. Handbook of Physicalchemical Properties and Environmental Fate for Organic Chemicals, vol. 2, CRC Press.

Mandalakis M., Tsapakis M., Tsoga A. and Stephanou E.G. (2002), Gas-particle concentration and distribution of aliphatic hydrocarbons, PAHs, PCBs and PCDD/Fs in the atmosphere of Athens (Greece), Atmospheric Environment, 36, 4023-4035.

Martinez K., Austrui J.R., Jover E., Ábalos M., Rivera J. and Abad E. (2010), Assessment of the emission of PCDD/Fs and dioxin-like PCBs from an industrial area over a nearby town using a selective wind direction sampling device, Environmental Pollution, 158, 764-769.

McKay G. (2002), Dioxin characterisation, formation and minimisation during municipal solid waste (MSW) incineration: review, Chemical Engineering Journal, 86(3), 343-368.

Min Y., Lee M., kim D. and Heo J. (2013), Annual and seasonal variations in atmospheric PCDDs/PCDFs and dioxin-like PCBs levels in satellite cities of Seoul, Korea during 2003-2009, Atmospheric Environment, 77, 222-230.

Ni Y., Zhang H., Fan S., Zhang X., Zhang Q. and Chen J. (2009), Emissions of PCDD/Fs from municipal solid waste incinerators in China, Chemosphere, 75(9), 1153-1158.

Oh J.E., Choi J.S. and Chang Y.S. (2001), Gas/particle partitioning ofpolychlorinated dibenzo-p-dioxins and dibenzofurans in atmosphere; evaluation of predicting models, Atmospheric Environment, 35, 4125-4134.

Oh J.E., Chang Y.S., Kim E.J. and Lee D.W. (2002), Distribution of polychlorinated dibenzop-dioxins and dibenzofurans (PCDD/Fs) in different sizes of airborne particles, Atmospheric Environment, 36(32), 5109-5117.

Pereira M.D. (2004), Polychlorinated dibenzo-p-dioxins (PCDD), dibenzofurans (PCDF) and polychlorinated biphenyls (PCB): main sources, environmental behaviour and risk to man and biota, Química Nova, 27(6), 934-943.

Qin S., Zhu X., Wang W., Chen J., Ni Y., Li X., Mu J., Xu Q. and Schramm K.W. (2012), Concentrations and gas-particle partitioning of PCDD/Fs in the urban air of Dalian, China. Chinese Science Bulletin, 57(26), 3442-3451.
Saral A., Gunes G., Karadeniz A. and Goncaloglu B.I. (2015), Gas/particle partitioning of PCDD/F compounds in the atmosphere of Istanbul, Chemosphere, 18, 246-252.

Shih M., Lee W.S., Chang-Chien G.P., Wang L.C., Hung C.Y. and Lin K.C. (2006), Dry deposition of polychlorinated dibenzo-pdioxins and dibenzofurans (PCDD/Fs) in ambient air, Chemosphere, 62(3), 411-416.

Simcik M.F., Zhang H., Eisenreich S.J. and Franz Th.P. (1997), Urban contamination of the Chicago/Coastal Lake Michigan atmosphere by PCBs and PAHs during AEOLOS, Environmental Science and Technology, 31, 2141-2147.

Sofuoglu A., Cetin E., Bozacioglu S.S., Sener G.D. and Odabasi M. (2004), Short-term variation in ambient concentrations and gas/particle partitioning of organochlorine pesticides in Izmir, Turkey, Atmospheric Environment, 38, 4483-4493

Stockholm Convention on Persistent Organic Pollutants (POPs) as amended in 2009. Text and Annexes.

Taşdemir Y. (1997), Modification and Evaluation of Water Surface Sampler to Investigate the Dry Deposition and AirWater Exchange of Polychlorinated Biphenyls (PCBS). Doctorate Thesis, Illinois Institiute of Technology, Chicago, IL, ABD.

Thuan N.T., Chi K.H., Wang S.H., Chang M.B., Lin N.H., Sheu G.R. and Peng C.M. (2013), Atmospheric PCDD/F measurement in taiwan and Southeast Asia during dongsha experiment, Atmospheric Environment, 78, 195-202.

Tian Y.J., Nie Z.Q., Tian S.L., Liu F., He J., Yang Y.F., Wang X.R., Die Q.Q., Fang Y.Y. and Huang Q.F. (2015), Passive air sampling for determining the levels of ambient PCDD/Fs and their seasonal and spatial variations and inhalation risk in Shanghai, China. Environmental Science \& Pollution Research Control Ser., 22(17), 13243-13250.

Trinh M.M. and Chang M.B. (2018), Review on occurrence and behavior of PCDD/Fs and dl-PCBs in atmosphere of East Asia, Atmospheric Environment, 180, 23-36.

Trinh M.M., Tsai C.L., Hien T.T., Thuan N.T., Chi K.H., Lien, C.G. and Chang M.B. (2018), Atmospheric concentrations and gas-particle partitioning of PCDD/Fs and dioxin-like PCBs around Hochiminh city, Chemosphere, 202, 246-254.

Tuppurainen K., Halonen I., Ruokojärvi P., Tarhanen J. and Ruuskanen J. (1998), Formation of PCDDs and PCDFs in municipal waste incineration and its inhibition mechanisms: a review, Chemosphere, 36(7), 1493-1511.

US EPA, Method TO 9A. Determination of Polychlorinated, Polybrominated and Brominated/Chlorinated Dibenzo-pDioxins and Dibenzofurans in the Ambient Air, EPA/625/R96/010b, 1999.

Weber R., lino F., Imagawa T., Takeuchi M., Sakurai T. and Sadakata M. (2001), Formation of PCDF, PCDD, PCB, and PCN in de novo synthesis from $\mathrm{PAH}$ : mechanistic aspects and correlation to fluidized bed incinerators, Chemosphere, 44(6), 1429-1438.

Wethington D.M. and Hornbuckle K.C. (2005), Milwaukee, WI, as a source of atmospheric PCBs to Lake Michigan, Environmental Science \& Technology, 39(1): 57-63.

Yeo H.G., Choi M., Chun M.Y. and Sunwoo Y. (2003), Gas/particle concentrations and partitioning of PCBs in the atmosphere of Korea. Atmospheric Environment, 37(25), 3561-3570. 